Anthracoceros albirostris used them for breeding. However, wooden boxes decay rapidly and are often colonized by stingless bees, civets, ants or flying squirrels, making them unsuitable for attracting large hornbill species. In 2020, no hornbills used the artificial or natural cavities during the breeding season (May-November) in Kinabatangan, possibly because rainfall was heavier than usual. Before the 2021 breeding season, we will erect more artificial nest boxes built with plastic drums, which last longer in harsh weather and tropical conditions. Although the occupancy rate of artificial nest boxes is less than $10 \%$, this project gives us hope to sustain breeding populations of large hornbill species in degraded forests, which are becoming the norm across the range of most hornbills in Asia.

Mark VerCoe and CAT Barton Chester Zoo, Chester, UK

RAVINDER KAUR Gaia, Kuala Lumpur, Malaysia

Remi Figueira Zoo Parc de Beauval, Saint Aignan sur Cher, France

Bryan Macaulay and Marisa Boyd Phoenix Zoo, Phoenix, USA

Marc AnCRENAZ (๑ orcid.org/0000-0003-2325-2879) Hutan, Kota Kinabalu, Sabah, Malaysia

E-mailmarc.ancrenaz@yahoo.com

This is an Open Access article, distributed under the terms of the Creative Commons Attribution licence CC BY 4.0

\section{New records of the Andean cat in central Chile- a challenge for conservation}

The Andean cat Leopardus jacobita is a small felid that inhabits the Andes of Argentina, Peru, Bolivia and Chile, and some areas of northern Patagonia. The species lives at a low population density, with an estimate of no more than 1,400 individuals throughout its range. Habitat loss and degradation are the main threats to this species and it is categorized as Endangered on the IUCN Red List. In Chile, it occurs discontinuously in foothill and high Andean areas from the extreme north (the Arica and Parinacota region) to the central area (the Metropolitan region). Although individuals have been recorded in the Coquimbo and Metropolitan regions, there have previously been no records in the vast connecting landscape of the Valparaíso region.

On 30 January 2020, however, during monitoring using camera traps, we recorded the species for the first time in the Valparaíso region, in the Rocin River basin, Putaendo $\left(32^{\circ} 28^{\prime} \mathrm{S} ; 70^{\circ} 25^{\prime} \mathrm{W}\right.$, at $2,330 \mathrm{~m}$ altitude), on 14 October 2020 a local farmer observed an Andean cat in a walnut orchard in a rural area of Putaendo $\left(32^{\circ} 31^{\prime} \mathrm{S} ; 70^{\circ} 38^{\prime} \mathrm{W}\right.$, at $1,115 \mathrm{~m}$ altitude), and on 17 October 2020 we recorded the species again with a

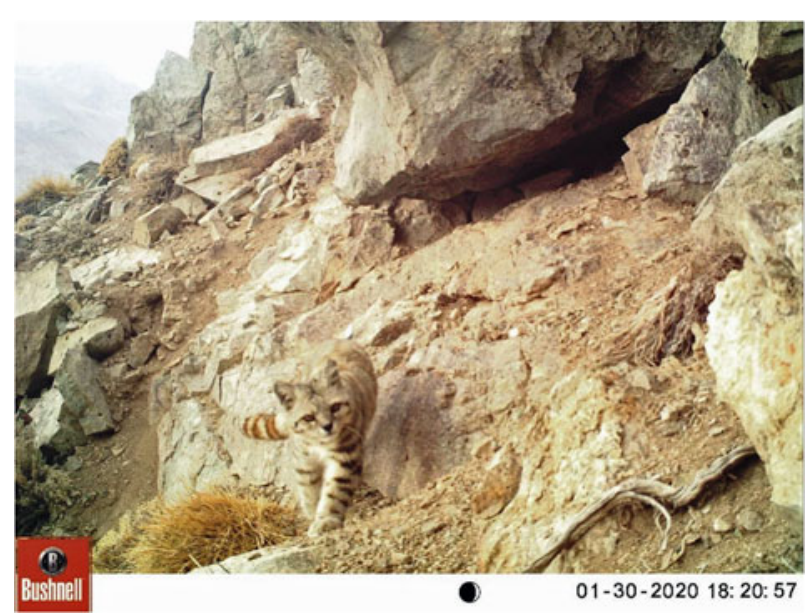

The Andean cat photo-trapped in the Valparaíso region on 30 January 2020. Photo: Bernardo Segura Silva.

camera trap in the Rocin River basin $\left(32^{\circ} 28^{\prime} \mathrm{S} ; 70^{\circ} 25^{\prime} \mathrm{W}\right.$, at $2,589 \mathrm{~m}$ altitude). These first records for the Valparaíso region improve our knowledge of the species' range, and of potential connectivity between the northern and central zones of Chile. The records in the Rocin River are of particular concern because a large-scale open pit mine is being developed in this area, with damage already caused by the construction of roads and establishment of drilling platforms. Conservation efforts for the Andean cat should focus on long-term monitoring of the species at these sites, further surveys for the species, and increasing the awareness and engagement of communities and private landowners regarding the need to protect the habitat of this species.

BERNARDo SEGURA SILVA (๑ orcid.org/0000-0001-6269-523X) Flora y Fauna Chile, Santiago, Chile, and Andean Cat Alliance, Córdoba, Argentina

E-mail bernardo.segura86@gmail.com

SOLANGE P. VARGAS (@ orcid.org/0000-0001-8953-6220) Universidad de La Serena-Universidad Católica del Norte, La Serena, Chile

Guillermo SAPAj-Aguilera (๑ orcid.org/0000-0002-86387503) ASÍ Conserva Chile, Santiago, Chile

RICARDo PINo Riffo Leopardus Austral Proyect, Gestión Ambiental Consultores, Santiago, Chile

This is an Open Access article, distributed under the terms of the Creative Commons Attribution licence CC BY 4.0

\section{Conservation of the Yangtze River Basin, China}

The Yangtze River flows for c. 6,300 km from the QinghaiTibetan Plateau to the Yellow Sea at Shanghai, with a watershed $>1,800,000 \mathrm{~km}^{2}, 20 \%$ of China's land area. This immense system of rivers and lakes has a rich biodiversity, including many endemics, and provides multiple ecosystem 
services. Although the river also supports a large human population and generates $>30 \%$ of China's GDP, it faces many severe ecological and environmental challenges. China has, however, proposed sustainable development of the whole Yangtze River system. Following visits by President Xi Jinping to Chongqing, Wuhan and Nanjing in the upper, middle and lower reaches of the Yangtze River in 2016, 2018 and 2020, respectively, he decreed that conservation and restoration, and avoidance of excessive development, must become priorities.

In 2020, a 10-year ban on fishing in the Yangtze River was implemented by the Ministry of Agriculture and Rural Affairs, with fishing in all tributaries prohibited. The effects of this ban are already clear in the lower reach of Yuan River, a tributary of the Yangtze River, where a larger population of scaly-sided merganser Mergus squamatus, a prodigious fish-eater, was able to overwinter in 2020 as a result of greater food availability.

The Landmark Yangtze River Protection Law was adopted by the National People's Congress Standing Committee, China's top legislature, on 24 December 2020, and entered into force on 1 March 2021 as the country's first legislation on a specific river basin. This law bans fishing in all natural waterways of the river, and in its tributaries, estuaries and feeder lakes. It consolidates conservation of the Yangtze River and provides a reference for development of legislation for other river basins.

To complement this law, a draft Wetland Protection Law was submitted to the Standing Committee of the National People's Congress on 20 January 2021. It is the country's first national legislation focused on conserving its wetlands. When passed, this second law will prohibit any organization or individual from destroying waterbird habitats and other wetland biodiversity.

PeIZHong LiU (๑ orcid.org/0000-0001-5387-1457),

MEIHAN LIU (৫ orcid.org/0000-0002-7875-3649),

GUANGCHUN LEI (@ orcid.org/0000-0001-9021-5758) and

QING ZENG (๑ orcid.org/0000-0002-7471-4941)

Beijing Forestry University, Beijing, China

E-mail guangchun.lei@foxmail.com

YIYU LI (@ orcid.org/0000-0002-3424-560X) Hunan

University of Arts and Science, Hunan, China

PETER BRIDGEWATER (@ orcid.org/0000-0001-7972-5386)

University of Canberra, Canberra, Australia

This is an Open Access article, distributed under the terms of the Creative Commons Attribution licence CC BY 4.0

\section{Rediscovery of rare shovelnose sturgeons in the Amu Darya River, Uzbekistan}

The small Amu Darya shovelnose sturgeon Pseudoscaphirhynchus hermanni (Acipenseridae) is a small, rare sturgeon species known only from the Amu Darya River in Central
Asia. It was last caught in 1996, in the middle reaches of the river (Salnikov et al., 1996, The Sturgeon Quarterly, 4, 10-14), and had not been recorded in its lower reaches since 1982 (Zholdasova, 1997, Environmental Biology of Fishes, 48, 373380). After the drying of the Aral Sea, habitat alterations in the Amu Darya River (overfishing, damming and channel management, extraction of water for irrigation, and water pollution) have led to a severe decline of sturgeon species there. In 1996, P. hermanni was categorized as Critically Endangered on the IUCN Red List.

On three occasions in 2020 (18-21 January, 14 March and 3 August), we searched for this species in the lower reaches of the Amu Darya. In a $55 \mathrm{~km}$ stretch of the river in the Khorezm Region of Uzbekistan, we collected five fish with the typical morphology of $P$. hermanni (i.e. a dark morph with a short snout). In addition, we caught four individuals of the Amu Darya shovelnose sturgeon Pseudoscaphirhynchus kaufmanni, which is also Critically Endangered. Pseudoscaphirhynchus hermanni can be distinguished from P. kaufmanni by its lack of a caudal filament, lack of spines on the snout, a shovel-shaped snout, pectoral fins with a fold that curls dorsally, and its small size.

Although they are rare and probably declining, our findings confirm that both P. hermanni and P. kaufmanni are still present in the Amu Darya River. Unfortunately, there has been no known reproduction of these species in captivity. Conservation efforts for both species are needed urgently.

BAKHTIYOR SHERALIEV (๑ orcid.org/0000-0003-3966-7403) School of Life Sciences, Southwest University, Chongqing, China

AkBARJON RozImov Faculty of Life Sciences, Urgench State University, Urgench, Uzbekistan

ARNE LUDWIG (๑ orcid.org/0000-0001-7249-9953) IUCN Sturgeon Specialist Group, Department of Evolutionary Genetics, Leibniz-Institute for Zoo and Wildlife Research, Berlin, Germany, and Thaer-Institute, Faculty of Life Sciences, Humboldt University Berlin, Berlin, Germany

Zuogang Peng (๑ orcid.org/0000-0001-8810-2025) IUCN Sturgeon Specialist Group, and Key Laboratory of Freshwater Fish Reproduction and Development (Ministry of Education), Southwest University School of Life Sciences, Chongqing, China.E-mail pzg@swu.edu.cn

This is an Open Access article, distributed under the terms of the Creative Commons Attribution licence CC BY 4.0

\section{Impact of the COVID-19 pandemic on conservation of the Javan gibbon}

The Coffee and Primate Conservation Project was initiated in 2012 to conserve the Javan gibbon Hylobates moloch and its habitat in the western Dieng Mountains, Central Java, 